\title{
Case Report of Cardiac Metastasis from Cervical Squamous Carcinoma and its Literature Review
}

\author{
Mingwei Yang ${ }^{1 *}$, Lin Yang ${ }^{1}$, Fan Wang ${ }^{1}$, Xuegong Shi ${ }^{2}$, Hao Wang ${ }^{1}$, Qibing Wu ${ }^{1}$, Yin Lv ${ }^{1}$ and \\ Xiangxun Chen ${ }^{1}$ \\ ${ }^{1}$ Department of Radiation Oncology, Anhui Medical University, P.R. China \\ ${ }^{2}$ Department of Cardiology, Anhui Medical University, P.R. China
}

*Corresponding author: Mingwei Yang, Department of Radiation Oncology, Anhui Medical University, P.R. China, Tel: 0551-65161000; E-mail: yangmw_ayyfy@126.com

Rec date: March 16, 2018; Acc date: May 14, 2018; Pub date: May 18, 2018

Citation: Yang M, Yang L, Wang F, Shi X, Wang H, et al. (2018) Case Report of Cardiac Metastasis from Cervical Squamous Carcinoma and its Literature Review. Gynecol Obstet Case Rep Vol.4: No.2: 65.

\section{Abstract}

We reported a case of a symptomatic metastasis of squamous cell carcinoma of the uterine cervix (SCCUC) to the right ventricle, then to the right atrium and superior vena cava five years later than the first SCCUC diagnosis. Because of the persistent thrombocytopenia, the treatment was discontinued after only one cycle of reduced paclitaxel liposome five years ago. The patient died six weeks after the diagnosis of cardiac metastasis. We reviewed the literatures in last two decades for the epidemiology, clinical presentation, diagnosis, treatment and prognosis of SCCUC with cardiac metastasis (SCCUC$\mathrm{CM}$ ). Dyspnea and chest pain are the common clinical presentations. Echocardiography, cardiac computed tomography (CT) and cardiac magnetic resonance imaging (CMR) are recommended in diagnosis. The prognosis for cardiac metastasis is extremely poor, with a median survival time of 5 months. Thrombocytopenia is a negative factor in the survival time of SCCUC-CM. Aggressive therapy including surgical intervention, chemotherapy, and whole heart radiation therapy may prolong survival time.

Keywords: Squamous cell carcinoma; Uterine cervix; Cardiac metastasis

\section{Introduction}

It is common to find metastasis of squamous cell carcinoma of the uterine cervix (SCCUC) in lungs, liver, bones and supraclavicular lymph nodes. But intracavitary cardiac metastasis (CM) is rarely reported. In this study, a case of antemortem SCCUC with cardiac metastasis (SCCUC-CM) was reported, and the corresponding literatures were reviewed. In this study, we found that an early diagnosis of $\mathrm{CM}$ and aggressive treatment may prolong the survival time, especially for those with solitary metastasis and in good general conditions.

\section{Case Report}

A 46-year-old Chinese female was admitted in the department of gynecology of the first affiliated hospital of Anhui medical university in March 2012, with a complaint of contact vaginal bleeding repeated for 6 months. The blood loss was bright red in color and not much in volume. In the gynecologic examination, a cauliflower-like mass about $3 \mathrm{~cm}$ in length was detected in uterine cervix (stage IB1). Biopsy showed squamous cell carcinoma. Pelvic magnetic resonance imaging (MRI) confirmed the stage IB1. No other positive findings in general and systemic examination was found. Then the patient received a radical hysterectomy along with pelvic and para-aortic lymph nodes dissection, followed by only cycle of paclitaxel and cisplatin due to intolerance. For external beam radiotherapy, whole pelvic irradiation of 50Gy was delivered in 25 fractions in 5 weeks. Pathologic findings revealed that the primary cervical mass was $2.2 \times 2 \mathrm{~cm}$, squamous cell carcinoma, moderate differentiation with more than $1 / 2$ myometrial invasion and vascular invasion. Follow-up examinations after the treatment included laboratory tests, gynecologic examinations and imaging tests (pelvic MRI, chest computed tomography [CT] and abdominal ultrasound). The results indicated no recurrence or metastasis. However, swellings in bilateral supraclavicular and mediastinal lymph nodes were identified in a follow-up CT 9 months later. The area of lymphatic metastasis was treated with radiation concurrent with four cycles of paclitaxel and cisplatin. After the treatment, swollen lymph nodes disappeared. In November 2017, the patient was admitted with a complaint of cough, chest pain and dyspnea. Electrocardiogram (ECG) displayed a flattened T-wave in leads III, aVL, aVF, V4-V6. The patient denied any history of cardiovascular disease. Further examinations were taken. The chest $\mathrm{CT}$ revealed the enlargement in the left axillary lymph nodes, bilateral hilar lymph nodes and multiple mediastinal lymph nodes, and the emboli in the right pulmonary artery (Figure 1). The transthoracic echocardiography revealed the presence of a mass occupying the right ventricle (Figure 2). The whole-body positron-emitting tomography computed tomography (PET-CT) showed the fluorodeoxyglucose (FDG) accumulation in the 
right ventricle, bilateral supraclavicular lymph nodes, left axillary lymph nodes, bilateral hilar lymph nodes and multiple mediastinal lymph nodes (Figure 3). Considering the medical history, the patient was suspected with cardiac and multiple lymph nodes metastasis of SCCUC. Biochemical tests revealed elevated fibrin degradation products $(17.11 \mu \mathrm{g} / \mathrm{ml}$; normal range, $0-5.00 \mu \mathrm{g} / \mathrm{ml})$ and D-dimers $(5.99 \mu \mathrm{g} / \mathrm{ml}$; normal range, $0-0.55 \mu \mathrm{g} / \mathrm{ml})$, alongside thrombocytopenia $\left(25 \times 10^{-9} / \mathrm{L}\right.$; normal range, $\left.125-350 \times 10^{-9} / \mathrm{L}\right)$. Bone marrow examinations revealed normal hematopoiesis. Because of the thrombocytopenia, chemotherapy was not given until the emerging of facial and neck edema. The second transthoracic echocardiography indicated that the mass progressed to the right atrium (RA) and superior vena cava (SVC) (Figure 2). After discussion with the patient's families and the patient, we decided to give reduced dose of paclitaxel liposome (120 $\mathrm{mg} / \mathrm{m}^{2}$ ). The patient's symptoms deteriorated two weeks after the chemotherapy and died six weeks after the diagnosis of cardiac metastasis. Her families refused an autopsy.

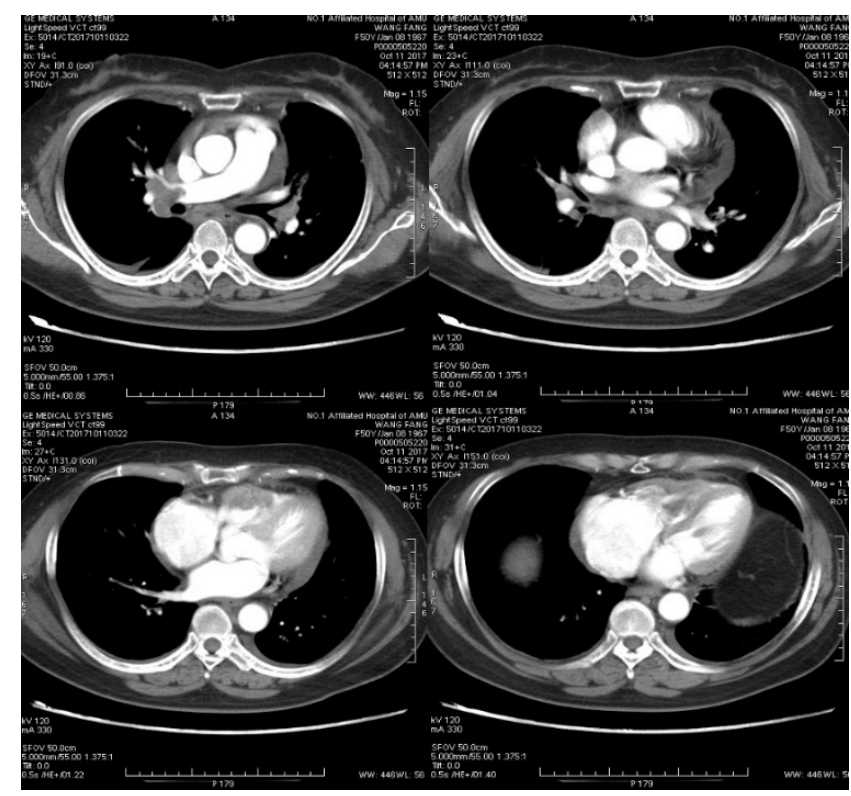

Figure 1 Chest computed tomography taken on October 11, 2017. It shows the enlargement in the left axillary lymph nodes, bilateral hilar lymph nodes and multiple mediastinal lymph nodes, and the emboli in the right pulmonary artery. Cardiac mass in the right heart was suspected.

\section{Discussion}

We searched the literatures in PubMed between 1998 and 2018. Fifteen articles with 16 cases were included, which presented a clinical course and treatment of antemortem SCCUC-CM (Table 1) [1-15]. The mean age of initial diagnosis of cervical cancer was 49 years old but varied widely from 27 to 79 years old. The stage at which the patients were diagnosed also varied widely, ranging from stage I to IV. The pathologic type was all squamous cell carcinoma. The median duration from the first diagnosis to $\mathrm{CM}$ in the reported cases was 15 months. The median interval from diagnosis of $\mathrm{CM}$ to death was 5 months for patients treated with surgery and/or chemotherapy, 6 months for radiation and/or chemotherapy, and 1.5 months with thrombocytopenia. Two patients had the longest survival time for more than one year, because CM was solitary and aggressive treatment was arranged. As is known, there are four routes in Cardiac Metastasis (CM): (1) Retrograde lymphatic spreading, (2) Direct extension from the adjacent viscera, (3) Hematogenous spreading, and (4) Transvenous extension through the vena cava into the rightside chambers.

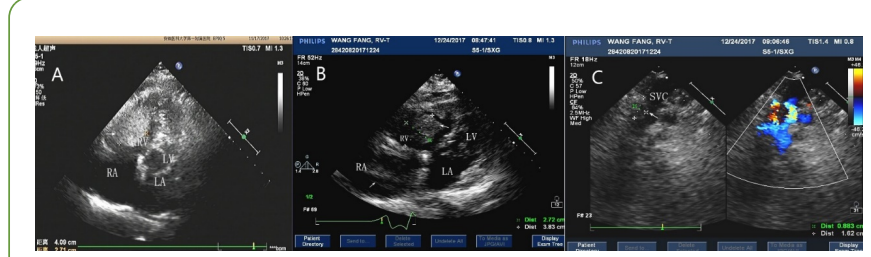

Figure 2 A: Transthoracic echocardiography taken on November 17, 2017. The mass was $4.1 \times 2.7 \mathrm{~cm}$ arising from the right ventricle. B, C: Transthoracic echocardiography taken on December 24, 2017. The masses occupied the right ventricle (RV), right atrium (RA) and superior vena cave (SVC).

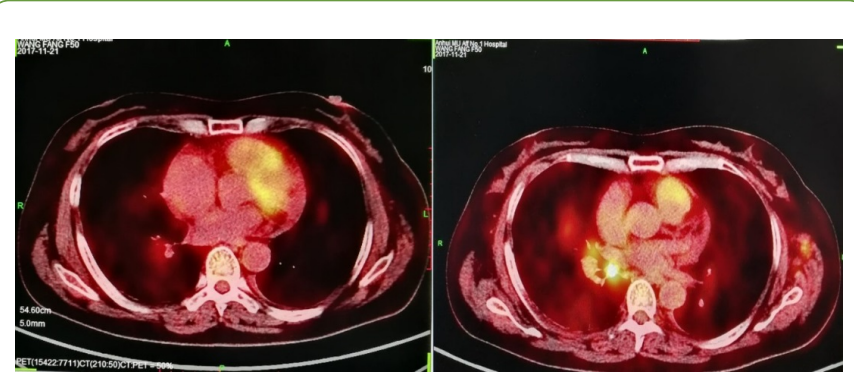

Figure 3 Positron-emitting computed tomography of heart taken on November 27, 2017. It shows a higher fluorodeoxyglucose uptake of the right ventricle due to the right ventricular mass.

After analyzing the images from transthoracic echocardiography in two time points with patient's clinical manifestations, we considered that the carcinoma metastasized from the cervix to the right ventricle firstly. Due to the high pressure in the right ventricle and no effective treatment, it spreaded to the right atrium and superior vena cava. For most of the reported cases, the spreading route of these cervical carcinomas was hematogeneous through the cervical plexus, inferior vena cave (IVC) into right atrium, and finally the right ventricle [1]. In Nakao's study, they reported a patient with carcinoma of the uterine cervix developed metastatic tumors in the para-aortic lymph nodes and extended through the IVC into the RA [8]. 
Table 1 Cases of cervical cancer with cardiac metastasis.

\begin{tabular}{|c|c|c|c|c|c|c|c|c|c|c|c|c|c|c|}
\hline $\begin{array}{l}\text { Auth } \\
\text { ors } \\
\text { (Year } \\
\text { ) }\end{array}$ & $\begin{array}{l}\text { Age } \\
\text { of } \\
\text { diag } \\
\text { nosi } \\
\mathrm{s} \text { of } \\
\text { cervi } \\
\text { cal }\end{array}$ & $\begin{array}{l}\text { st } \\
\text { ag } \\
\text { e }\end{array}$ & $\begin{array}{l}\text { Patho } \\
\text { logic } \\
\text { Type }\end{array}$ & $\begin{array}{l}\text { Interv } \\
\text { al to } \\
\text { cardi } \\
\text { ac } \\
\text { meta } \\
\text { stasis }\end{array}$ & $\begin{array}{l}\text { Clinical } \\
\text { present } \\
\text { ation }\end{array}$ & $\begin{array}{l}\text { locat } \\
\text { ion }\end{array}$ & $\begin{array}{l}\text { Prima } \\
\text { ry } \\
\text { treat } \\
\text { ment }\end{array}$ & $\begin{array}{l}\text { treat } \\
\text { ment }\end{array}$ & $\begin{array}{l}\text { Interv } \\
\text { al } \\
\text { from } \\
\text { cardi } \\
\text { ac } \\
\text { meta } \\
\text { stasis }\end{array}$ & $\begin{array}{l}\text { Solit } \\
\text { ary } \\
\text { (yes } \\
\text { or } \\
\text { no) }\end{array}$ & diagnosis & $\begin{array}{l}\text { thrombocy } \\
\text { topenia }\end{array}$ & ECG & $\begin{array}{l}\text { Over } \\
\text { all } \\
\text { survi } \\
\text { val } \\
\text { (mon } \\
\text { ths) }\end{array}$ \\
\hline $\begin{array}{l}\text { Yang } \\
(201 \\
8)\end{array}$ & 46 & $\begin{array}{l}\text { IB } \\
1\end{array}$ & $\begin{array}{l}\text { squa } \\
\text { mous }\end{array}$ & 68 & $\begin{array}{l}\text { Dypenia } \\
\text { and } \\
\text { chest } \\
\text { pain }\end{array}$ & $\mathrm{RV}$ & $\begin{array}{l}\mathrm{S} \text { and } \\
\text { adjuva } \\
\mathrm{nt} \mathrm{RT}\end{array}$ & $\begin{array}{l}\text { Palliat } \\
\text { ive } \\
\text { treatm } \\
\text { ent } \\
\text { and C }\end{array}$ & 1.5 & no & $\begin{array}{l}\text { Echocardio } \\
\text { graphy, CT } \\
\text { and } \\
\text { PET/CT }\end{array}$ & yes & $\begin{array}{l}\text { Flattene } \\
\text { d T- } \\
\text { wave in } \\
\text { leads } \\
\text { III, aVL, } \\
\text { aVF, } \\
\text { V4-V6 }\end{array}$ & 70 \\
\hline $\begin{array}{l}\text { Han } \\
(201 \\
7)\end{array}$ & 44 & IV & $\begin{array}{l}\text { squa } \\
\text { mous }\end{array}$ & 0 & $\begin{array}{l}\text { Dypenia } \\
\text { and } \\
\text { chest } \\
\text { pain }\end{array}$ & $\mathrm{RV}$ & $\begin{array}{l}\mathrm{S} \text { and } \\
\mathrm{C}\end{array}$ & $\begin{array}{l}\mathrm{S} \text { and } \\
\mathrm{C}\end{array}$ & 15 & yes & $\begin{array}{l}\text { PET/ CT } \\
\text { echocardio } \\
\text { graphy and } \\
\text { operation }\end{array}$ & NR & NR & 15 \\
\hline $\begin{array}{l}\text { Tsuc } \\
\text { hida } \\
(201 \\
6)\end{array}$ & 79 & $\begin{array}{l}\text { IB } \\
1\end{array}$ & $\begin{array}{l}\text { squa } \\
\text { mous }\end{array}$ & 12 & $\begin{array}{l}\text { Epigastr } \\
\text { ic } \\
\text { discomf } \\
\text { ort and } \\
\text { general } \\
\text { malaise }\end{array}$ & $\mathrm{RV}$ & RT & $\begin{array}{l}\text { Supp } \\
\text { ortive } \\
\text { treatm } \\
\text { ent }\end{array}$ & 1 & yes & $\begin{array}{l}\text { Transthora } \\
\text { cic } \\
\text { echocardio } \\
\text { graphy, CT, } \\
\text { MRI }\end{array}$ & Yes & $\begin{array}{l}\text { Low } \\
\text { voltage } \\
\text { amplitu } \\
\text { des in } \\
\text { leads } \\
\text { V1-V6 } \\
\text { and T- } \\
\text { wave } \\
\text { inversio } \\
\mathrm{n} \text { in } \\
\text { leads } \\
\text { V3-V6 }\end{array}$ & 13 \\
\hline $\begin{array}{l}\text { Oka } \\
\text { moto } \\
(201 \\
5)\end{array}$ & 27 & $\begin{array}{l}\text { IB } \\
1\end{array}$ & $\begin{array}{l}\text { squa } \\
\text { mous }\end{array}$ & 15 & $\begin{array}{l}\text { asympt } \\
\text { omatic }\end{array}$ & $\mathrm{RV}$ & $\begin{array}{l}\text { S, C } \\
\text { and } \\
\text { RT }\end{array}$ & none & $\begin{array}{l}0.7 \\
(21 \\
\text { days })\end{array}$ & no & $\begin{array}{l}\text { PET and } \\
\text { CT }\end{array}$ & yes & NR & 16 \\
\hline $\begin{array}{l}\text { Scha } \\
\text { wkat } \\
(201 \\
4)\end{array}$ & 31 & IIB & $\begin{array}{l}\text { squa } \\
\text { mous }\end{array}$ & 15 & $\begin{array}{l}\text { Dyspne } \\
\text { a and } \\
\text { feve }\end{array}$ & $\begin{array}{l}\text { LV } \\
\text { and } \\
\text { RV }\end{array}$ & $\begin{array}{l}\mathrm{S} \text { and } \\
\text { adjuva } \\
\mathrm{nt} \\
\mathrm{CRT}\end{array}$ & $\mathrm{C}$ & NR & no & $\begin{array}{l}\text { Transthora } \\
\text { cic } \\
\text { echocardio } \\
\text { graphy, } \\
\text { MRI and } \\
\text { transcathet } \\
\text { er biopsy }\end{array}$ & NR & $\begin{array}{l}\text { ST- } \\
\text { segmen } \\
t \text { in V3- } \\
\text { V6 }\end{array}$ & NR \\
\hline $\begin{array}{l}\text { Byun } \\
(201 \\
3)\end{array}$ & 32 & $\begin{array}{l}\mathrm{IIA} \\
2\end{array}$ & $\begin{array}{l}\text { squa } \\
\text { mous }\end{array}$ & 15 & $\begin{array}{l}\text { Exertion } \\
\text { al } \\
\text { dyspne } \\
\text { a }\end{array}$ & $\begin{array}{l}\text { RV } \\
\text { and } \\
\text { RA }\end{array}$ & $\begin{array}{l}\mathrm{S} \text { and } \\
\text { adjuva } \\
\mathrm{nt} \\
\mathrm{CRT}\end{array}$ & $\begin{array}{l}\mathrm{S} \text { and } \\
\mathrm{C}\end{array}$ & 13 & NR & $\begin{array}{l}\text { Echocardio } \\
\text { graphy, } \\
\text { Chest CT } \\
\text { and } \\
\text { operation }\end{array}$ & NR & NR & 32 \\
\hline $\begin{array}{l}\text { Bors } \\
\text { aru } \\
(200 \\
7)\end{array}$ & 42 & $\begin{array}{l}\text { IV } \\
\text { B }\end{array}$ & $\begin{array}{c}\text { squa } \\
\text { mous }\end{array}$ & 6 & $\begin{array}{l}\text { Chest } \\
\text { pain } \\
\text { and } \\
\text { respirat } \\
\text { oty } \\
\text { distress }\end{array}$ & $\begin{array}{l}\text { RV } \\
\text { and } \\
\text { RA }\end{array}$ & RT & $S$ & NR & NR & $\begin{array}{l}\text { Echocardio } \\
\text { graphy CT } \\
\text { and } \\
\text { operation }\end{array}$ & yes & NR & NR \\
\hline $\begin{array}{l}\text { Naka } \\
\text { o }\end{array}$ & 57 & $\begin{array}{l}\text { III } \\
B\end{array}$ & $\begin{array}{c}\text { squa } \\
\text { mous }\end{array}$ & 10 & $\begin{array}{l}\text { Cough, } \\
\text { chest } \\
\text { pain }\end{array}$ & RA & $\begin{array}{l}\text { Concu } \\
\text { rrent } \\
\text { CRT }\end{array}$ & $\mathrm{S}$ & 2 & no & $\begin{array}{l}\text { Echocardio } \\
\text { graphy and } \\
\text { operation }\end{array}$ & NR & NR & 12 \\
\hline
\end{tabular}




\begin{tabular}{|c|c|c|c|c|c|c|c|c|c|c|c|c|c|c|}
\hline $\begin{array}{l}(200 \\
6)\end{array}$ & & & & & $\begin{array}{l}\text { and } \\
\text { shortne } \\
\text { ss of } \\
\text { breath }\end{array}$ & & & & & & & & & \\
\hline $\begin{array}{l}\text { Ferra } \\
z \\
(200 \\
6)\end{array}$ & 63 & $\begin{array}{l}N \\
\mathrm{R}\end{array}$ & $\begin{array}{l}\text { squa } \\
\text { mous }\end{array}$ & NR & $\begin{array}{l}\text { Dyspne } \\
\text { a and } \\
\text { fatigue }\end{array}$ & $\mathrm{RV}$ & $\begin{array}{l}\text { S, C } \\
\text { and } \\
\text { RT }\end{array}$ & $S$ & $\begin{array}{l}\text { More } \\
\text { than } 5\end{array}$ & NR & $\begin{array}{l}\text { Echocardio } \\
\text { graphy and } \\
\text { operation }\end{array}$ & NR & $\begin{array}{l}\text { Area of } \\
\text { inactiva } \\
\text { tion in } \\
\text { anterior } \\
\text { wall } \\
\text { and } T \\
\text { wave } \\
\text { inversio } \\
n \text { in } \\
\text { leads } \\
\text { V3 and } \\
\text { V4 }\end{array}$ & NR \\
\hline $\begin{array}{l}\text { Saith } \\
0 \\
(200 \\
5)\end{array}$ & 68 & $\begin{array}{l}\text { III } \\
\text { B }\end{array}$ & $\begin{array}{l}\text { squa } \\
\text { mous }\end{array}$ & 15 & $\begin{array}{l}\text { Shortne } \\
\text { ss of } \\
\text { breath }\end{array}$ & RV & RT & $\begin{array}{l}S \text { and } \\
C\end{array}$ & 5 & yes & $\begin{array}{l}\text { Echocardio } \\
\text { graphy and } \\
\text { Chest CT }\end{array}$ & NR & NR & 20 \\
\hline $\begin{array}{l}\text { Feys } \\
(200 \\
5)\end{array}$ & 37 & $\begin{array}{l}\text { III } \\
\text { B }\end{array}$ & $\begin{array}{l}\text { squa } \\
\text { mous }\end{array}$ & NR & $\begin{array}{l}\text { Cough, } \\
\text { fever } \\
\text { and } \\
\text { short of } \\
\text { Breath } \\
\text { and } \\
\text { sweatin } \\
\text { g }\end{array}$ & RV & $\begin{array}{l}\text { RT } \\
\text { and C }\end{array}$ & $\begin{array}{l}\text { RT } \\
\text { and C }\end{array}$ & $\begin{array}{l}\text { More } \\
\text { than } 8\end{array}$ & no & $\begin{array}{l}\text { Echocardio } \\
\text { graphy and } \\
\text { PET/CT }\end{array}$ & NR & $\begin{array}{l}\text { Sinus } \\
\text { tachyca } \\
\text { rdia, } \\
\text { low } \\
\text { voltage } \\
\text { QRS } \\
\text { and } \\
\text { non- } \\
\text { specific } \\
\text { T-wave } \\
\text { abnorm } \\
\text { alities }\end{array}$ & NR \\
\hline $\begin{array}{l}\text { Inam } \\
\text { ura } \\
(200 \\
4)\end{array}$ & 58 & $\begin{array}{l}\text { IB } \\
1\end{array}$ & $\begin{array}{l}\text { squa } \\
\text { mous }\end{array}$ & 43 & $\begin{array}{l}\text { Chest } \\
\text { pain, } \\
\text { cough } \\
\text { and } \\
\text { dyspne } \\
\text { a }\end{array}$ & RV & $\begin{array}{l}\mathrm{S} \text { and } \\
\mathrm{C}\end{array}$ & $\begin{array}{l}\text { Palliat } \\
\text { ive S }\end{array}$ & 4 & no & $\begin{array}{l}\text { Echocardio } \\
\text { graphy and } \\
\text { CT }\end{array}$ & Yes & $\begin{array}{l}\text { Low } \\
\text { voltage } \\
\text { amplitu } \\
\text { des in } \\
\text { limb } \\
\text { and } \\
\text { chest } \\
\text { leads } \\
\text { and an } \\
\text { S }\end{array}$ & 48 \\
\hline $\begin{array}{l}\text { Iwaki } \\
(200 \\
1)\end{array}$ & 49 & $\begin{array}{l}N \\
\mathrm{R}\end{array}$ & $\begin{array}{l}\text { squa } \\
\text { mous }\end{array}$ & 0 & $\begin{array}{l}\text { Cough } \\
\text { and } \\
\text { low- } \\
\text { grade } \\
\text { fever }\end{array}$ & RV & I & CRT & 2 & no & $\begin{array}{l}\text { Echocardio } \\
\text { graphy and } \\
\text { biopsy }\end{array}$ & yes & 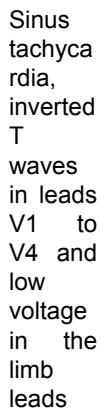 & 2 \\
\hline $\begin{array}{l}\text { Harv } \\
\text { ey } \\
(200 \\
0)\end{array}$ & 44 & $\begin{array}{l}\text { IB } \\
1\end{array}$ & $\begin{array}{l}\text { squa } \\
\text { mous }\end{array}$ & 6 & $\begin{array}{l}\text { asympt } \\
\text { omatic }\end{array}$ & RV & RT & $\begin{array}{l}S \text { and } \\
\text { RT, C }\end{array}$ & $\begin{array}{l}\text { More } \\
\text { than } 8\end{array}$ & yes & $\begin{array}{l}\text { Echocardio } \\
\text { graphy and } \\
\text { CT }\end{array}$ & NR & NR & $\begin{array}{l}\text { More } \\
\text { than } \\
14\end{array}$ \\
\hline $\begin{array}{l}\text { Lemu } \\
\mathrm{s} \\
(199 \\
8)\end{array}$ & 53 & IB & $\begin{array}{l}\text { squa } \\
\text { mous }\end{array}$ & 18 & $\begin{array}{l}\text { Dyspne } \\
\text { a }\end{array}$ & RV & $\begin{array}{l}\text { RT } \\
\text { and S }\end{array}$ & CRT & 1 & no & $\begin{array}{l}\text { Echocardio } \\
\text { graphy and } \\
\text { MRI }\end{array}$ & yes & NR & 19 \\
\hline $\begin{array}{l}\text { Lemu } \\
\mathrm{s} \\
(199 \\
8)\end{array}$ & 48 & $\begin{array}{l}\text { III } \\
\text { B }\end{array}$ & $\begin{array}{l}\text { squa } \\
\text { mous }\end{array}$ & 6 & $\begin{array}{l}\text { dyspne } \\
\text { a }\end{array}$ & RV & RT & CRT & 7 & no & $\begin{array}{l}\text { Echocardio } \\
\text { graphy and } \\
\text { MRI }\end{array}$ & yes & NR & 13 \\
\hline
\end{tabular}


Even though it was rare to see metastasis from para-aortic lymph nodes to the heart, the route was also in the way that the tumor extended into the IVC and growed into the right chamber. The right side of the heart was more commonly involved than the left side. Of the 17 cases including the current case, 16 occurred in the right side, one occurred in the right and the left side.

The possible reasons may include: (1) Direct seeding in the heart by microemboli from lymphatics and venous return, (2) The filtering of the pulmonary circulation, (3) The slower flow in the right chambers, and (4) The presence of pulmonary tumor emboli might decrease the right cardiac blood flow further, resulting in a more hospitable environment for tumor cell adherence to the endocardial wall.

Cardiac tumors are divided into primary and secondary tumors. Primary cardiac tumors are rare, and the incidence was $0.001-0.3 \%$ by autopsy, while metastatic tumors were reported to be 20 to 40 times more common by autopsy [16] For patients with known malignancy, the incidence of CM was $9 \%$ [17], and the risk of CM increased with a patient's overall metastatic burden [18]. Tumors with high rates of CM include lung cancers, breast cancers, hematologic malignancies and melanoma. Pleural mesothelioma and melanoma had an unusual proclivity to involve the heart, with an estimate of $28 \%$ to $56 \%$ of patients with metastatic melanoma having some cardiac involvement [18].

Of all the CM, intracavitary, endocardial, or valvular metastasis, such as the one described in our case, occurred less than $6 \%$. Eighty percent of all these types of metastasis in cervical carcinoma occurred in the right chambers and rarely in the left chambers. The prognosis of a metastatic heart tumor was poor, the average survival time for patients with this diagnosis was less than six months.

The severity of clinical symptoms in patients with CM was variable and differed depending on the extent and the localization within the heart. Cardiac metastasis may cause medical emergencies or more often no early symptoms and remain unrecognized until the postmortem autopsy. Dyspnea, palpitations, syncope and chest pain are common clinical presentations of CM. Congestive heart failure, cardiac arrhythmia, heart block, acute myocardial infarction, myocardial rupture and systemic embolization are other lifethreatening manifestations of CM. Other clinical manifestations include symptoms of pericarditis, pericardial effusion, and constrictive pericarditis may happen if pericardium is involvement. Of all the cases listed in Table 1, the most common clinical manifestations were: Dyspnea $12 / 17(71 \%)$ and chest pain $6 / 17(35 \%)$, others included cough and fever. Cardiac metastasis should be suspected if patients with cervical carcinoma have such complaints, particularly with other distant metastases or thoracic involvement.

Physical examination is of vital importance to find various hints of $\mathrm{CM}$ such as new murmurs from intracardiac masses. ECG acts as a useful but nonspecific technique, abnormalities in ECG can remind us the possibility of $\mathrm{CM}$. In our case, the ECG displayed flattened T-wave in leads III, aVL, aVF, V4-V6.
Non-invasive imaging plays a paramount role in investigating cardiac masses and establishing a diagnosis.

Most cardiac masses are initially detected by echocardiography which can offer information on the location, size, and mobility of cardiac masses. It was reported that the diagnostic accuracy of echocardiography was as high as $80 \%$ [19]. Limitations of echocardiography include low image quality, limited visualization of the entire wall of the apex and base of the heart and extra-cardiac structure. Cardiac CT and cardiac magnetic resonance imaging (CMR) have superb spatial resolution and image quality which can provide additional non-invasive characterization of cardiac masses. Also, they visualize extra-cardiac structures which are helpful to identify direct tumor extension from adjacent mediastinal structures. The tissue characterization capabilities of CMR can be used to differentiate infiltrating metastasis from myocardium, and tumor from thrombus. PET-CT is a non-invasive imaging technique used to detect occult or distant metastasis at a relatively early stage and to further clarify the existing abnormal radiologic findings.

It was reported that even in an individual, the cardiac uptake of FDP by left ventricle differed from that of the right ventricle. This masking causes difficulty in detection of any cardiac mass or lesion [20]. For intra-cardiac metastasis in the cervical carcinoma, characteristic on MRI are low signal intensity on T1-weighted imaging, high signal intensity on T2weighted imaging and mostly enhance. Thrombi and primary cardiac tumors should be taken into consideration when give the diagnosis of intracardiac metastasis. For thrombi, the most common place is the left heart, and it is hypo-intensive in T1and T2-weighted imaging and lacks internal enhancement [17].

In our case, decreased platelets and increased FDG and Ddimers were detected and impeded further effective treatment when $\mathrm{CM}$ was suspected. Bone marrow examination revealed normal hematopoiesis, so as the case reported by Kazuhiro Okamoto [3]. It may be the result of the consumption and destruction of platelets as blood flowed through the damaged myocardium, as well as the consumption of platelets in hypercoagulable state induced by tumor embolization and multiple pulmonary emboli.

Among the 8 cases, including current case, in which thrombocytopenia was reported, the interval from $\mathrm{CM}$ to death was shorter than those without thrombocytopenia, seven cases were shorter than 2 months, and only one case was 7 months. Our patient was very similar to the second patient reported by Julio F. Lemus [15] and the patient reported by Kazuhiro Okamoto [3].

The difference was that the second patient reported by Julio F. Lemus received aggressive therapy (radiation therapy with total delivery of $6000 \mathrm{cGy}$ to the heart concurrent with infusional 5-FU and cisplatin), thrombocytopenia was developed in the course of the therapy not prior to initiation of therapy. These may be the reason that this patient had a longer interval than other cases with thrombocytopenia. Considering all these information, we concluded the 
decreased platelets to be a negative prognostic factor for $\mathrm{CM}$ of cervical carcinoma.

Several studies recommended that aggressive treatment lengthened the patients' survival time. Byun et al. reported a case of 32-year-old female diagnosed as cervical cancer (squamous cell carcinoma) stage IIA2 with exertional dyspnea which was the result of metastatic cardiac mass. The patient was treated with surgical excision followed by chemotherapy using paclitaxel and carboplatin.

The patient survived for 13 months after the diagnosis of CM [5]. Han et al. reported a case of isolated intracavitary CM arising from squamous cell carcinoma of the cervix. The patient was treated with surgery followed by 12 cycles chemotherapy using paclitaxel and cisplatin. The patient died 14 months and 4 weeks after the diagnosis of CM [1]. Radiotherapy can also be an option some literatures reported their experience in treating $\mathrm{CM}$ with radiation. Only two patients completed a total delivery of $6000 \mathrm{cGy}$ to the heart.

The survival time for the two patients were 7 months and more than 8 months, respectively. Advances in computerguided imaging technology and radiation therapy planning technology enable radiation dose to reach the definitive dose to only the involved side of the heart, with no compromise to the other side of the heart. A total dose of $6000 \mathrm{cGy}$ is recommended. Aggressive treatment includes surgical resection, radiotherapy and systemic chemotherapy, which may help to prolong the overall survival for solitary $\mathrm{CM}$. Patients' general conditions, should also be taken into consideration.

\section{Conclusion}

Patients with SCCUC should be carefully monitored and followed up. For patients diagnosed in advanced stage, cardiac evaluation should be included in follow-ups. It is important to suspect the diagnosis of $\mathrm{CM}$ in patients with repetitious increased D-Dimers and FDG, decreased platelets, and the complaint of dyspnea and chest pain. Echocardiography, cardiac CT and CMR are useful in the diagnosis of CM. The prognosis for $\mathrm{CM}$ is extremely poor, the survival time for most patients was less 1 year, and even shorter, about 2 months for the patients with thrombocytopenia. So far, there is no standard treatment for SCCUC-CM. Aggressive therapies may prolong survival time, including surgical intervention, chemotherapy and whole heart radiation therapy. It is of vital importance to follow up and examine the high-risk patients so that proper intervention could be made in the early stage, which may be the most effective way to prolong the survival time of cervical carcinoma patients with cardiac metastasis.

\section{References}

1. Han GH, Kwon DY, Ulak R, Ki KD, Lee JM, et al. (2017) Right ventricular metastatic tumor from a primary carcinoma of uterine cervix: A cause of pulmonary embolism. Obstet Gynecol Sci 60: 129-132.
2. Tsuchida K, Oike T, Ohtsuka T, Ide M, Takakusagi Y, et al. (2016) Solitary cardiac metastasis of uterine cervical cancer with antemortem diagnosis: A case report and literature review. Oncology Letters 11: 3337-3341.

3. Okamoto K, Kusumoto T, Seki N, Nakamura K, Hiramatsu $Y$ (2015) A case of cardiac metastasis from uterine cervical carcinoma. Case Rep Obstet Gynecol 2015: 703424.

4. Schawkat K, Hoksch B, Schwerzmann M, Puig S, Klink T, et al. (2014) Diagnosis of cardiac metastasis from cervical cancer in a 33-year-old patient using multimodal imaging studies: a case report and literature review. Acta Radiol Short Rep 3: 2047981614530287.

5. Byun SW, Park ST, Ki EY, Song H, Hong SH, et al. (2013) Intracardiac metastasis from known cervical cancer: A case report and literature review. World J Surg Oncol 11: 1-5.

6. Miller ES, Hoekstra AV, Hurteau JA, Rodriguez GC (2010) Cardiac metastasis from poorly differentiated carcinoma of the cervix: a case report. J Reprod Med 55: 78-80.

7. Borsaru A D, Lau KK, Solin P (2007) Cardiac metastasis: A cause of recurrent pulmonary emboli. Br J Radiol 80: 50-53.

8. Nakao Y, Yokoyama M, Yasunaga M, Hara K, Nakahashi $\mathrm{H}$, et al. (2006) Metastatic tumor extending through the inferior vena cava into the right atrium: A case report of carcinoma of the uterine cervix with para-aortic lymph node metastases. Int J Gynecol Cancer 16: 914-916.

9. Ferraz JG, Martins AL, De Souza JF, Matos A, Canto AP, et al. (2006) Metastatic tumor of squamous cell carcinoma from uterine cervix to heart: Ante-mortem diagnosis. Arq Bras Cardiol 87: 104-107.

10. Feys A, Herregods MH (2005) Cardiac metastasis from a stage Illb cervix carcinoma. Acta Cardiologica 60: 73-75.

11. Saitoh Y, Aota M, Koike H, Nakane T, Iwasa Y, et al. (2005) Isolated right ventricular metastasis of uterine cervical carcinoma. Gen Thorac Cardiovasc Surg 53: 645.

12. Inamura K, Hayashida A, Kaji Y, Ito H, Harada M, et al. (2004) Recurrence of cervical carcinoma manifesting as cardiac metastasis three years after curative resection. Am J Med Sci 328: 167-169.

13. Iwaki T, Kanaya H, Namura M, Ikeda M, Uno Y, et al. (2001) Right ventricular metastasis from a primary cervical carcinoma. Jpn Circ J 65: 761-763.

14. Harvey RL, Sachdev V, Heath BJ (2000) Isolated cardiac metastasis of cervical carcinoma presenting as disseminated intravascular coagulopathy. A case reports. J Reprod Med 45: 603-606.

15. Lemus JF, Abdulhay G, Sobolewski C, Risch VR (1998) Cardiac metastasis from carcinoma of the cervix: A report of two cases. Gynecologic Oncology 69: 264.

16. Almamgani A, Baartman L, Baaijens M, De Pree I, Incrocci L, et al. (2008) Cardiac metastases. Int J Clin Oncol 13: 369-372.

17. Rd LJ, Reynolds DA, Keung J, Keung E, Carter BW (2016) Metastasis to the heart: A radiologic approach to diagnosis with pathologic correlation. Ajr Am J Roentgenol 207: 1-9.

18. Bussani R, Degiorgio F, Abbate A, Silvestri F (2007) Cardiac metastases. Journal of Clinical Pathology 60: 27-34.

19. Nomoto N, Tani T, Konda T, Kim K, Kitai T, et al. (2017) Primary and metastatic cardiac tumors: Echocardiographic diagnosis, 
treatment and prognosis in a 15 -years single center study. J Cardiothorac Surg 12: 103.

20. Orcurto MV, Delaloye AB, Letovanec I, Martins Favre M, Prior JO (2009) Detection of an asymptomatic right-ventricle cardiac metastasis from a small-cell lung cancer by F-18-FDG PET/CT. J Thorac Oncol 4: 127-130. 